\title{
The assessment of Female Students' Perceptions, Practices and Challenges in Cooperative Learning: The Case of Natural Science Stream of Mettu College of Teacher Education
}

\author{
Feyera Beyessa*
}

College of Education and Behavioural Sciences, Wollega University, Post Box: 395, Nekemte, Ethiopia

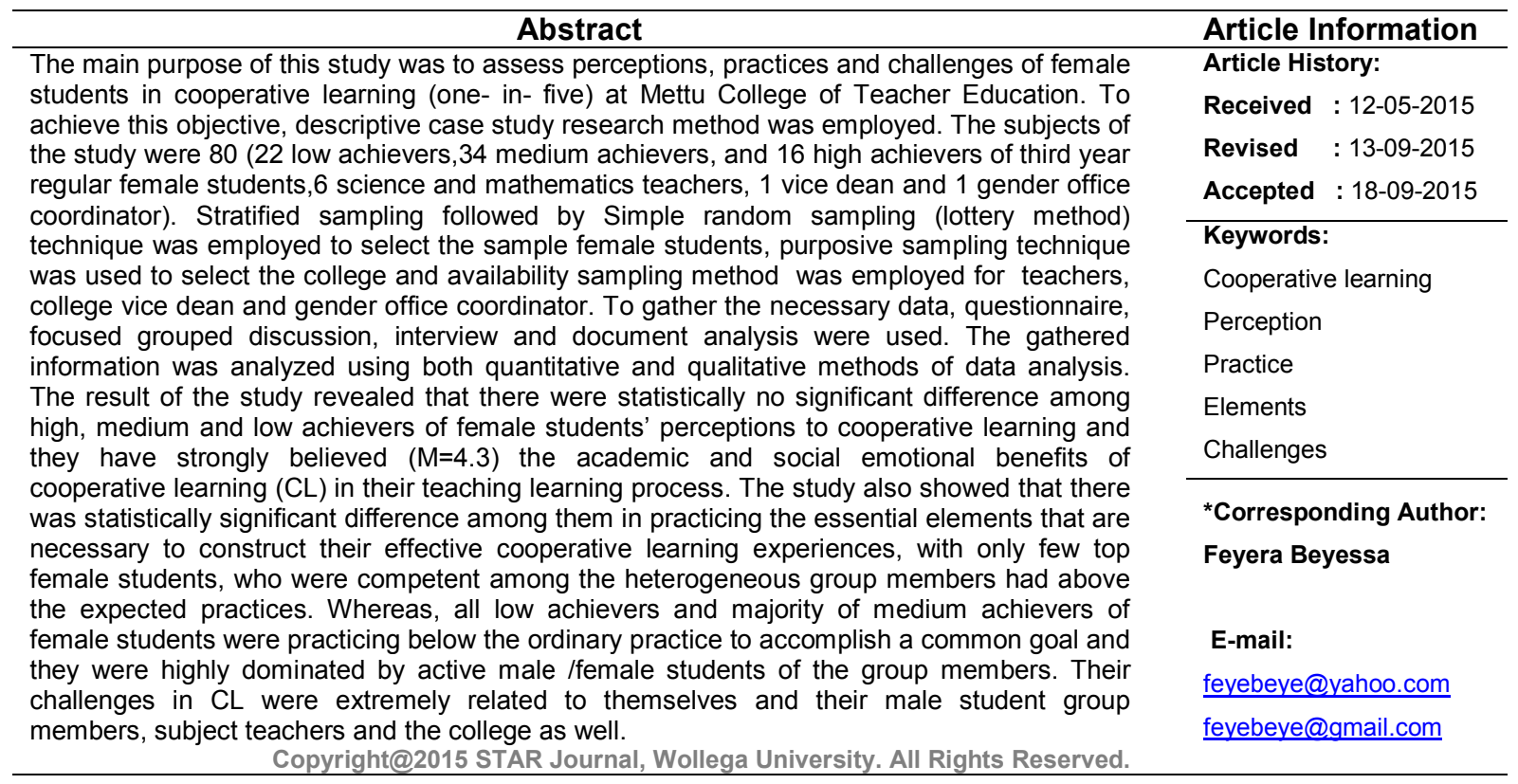

\section{INTRODUCTION}

Students learning together offer more benefits to student learning through personal and active student engagement in comparison to traditional instruction (Barkley, Cross and Major, 2005). Active learning with cooperative learning experiences has been recommended as an effective strategy for college level courses for the fact that cooperative learning $(\mathrm{CL})$ involves groups of students who work together to accomplish a common goal by: swimming together, learning together but performing alone, teaching one's knowledge to other, showing conflict-management skills and discussing how well they are achieving their goals (Johnson, Johnson, and Smith, 1991). Hence, cooperative learning helps learners to evaluate their own strengths and weaknesses, and encourages students to become reflective practitioners and strive for continuous improvement (Williams, 2007).

\section{Major Benefits of Cooperative Learning}

Cooperative learning is among the most well researched of all teaching strategies. Forty years of research has shown that when compared to other methods of instruction, cooperative learning is one of the most effective ways for students to maximize their own learning and the academic accomplishments of their classmates (Johnson and Johnson, 1994, Slavin, 1996, Williams, 2007).

\section{Academic Benefits}

Various studies show that effective implementation of cooperative learning in the college promotes significant cognitive results. One recent study of nearly 500 undergraduate engineering students from six diverse institutions indicated that cooperative learning produced "statistically significant and substantially greater gains in student learning than those associated with more traditional instructional methods." Even with differences in pre-course characteristics and learning advantages, levels of understanding and retention still increased in the cooperative learning settings (Terenzini et al., 2001). In a $\mathrm{CL}$ setting, students must not only articulate their understanding to their teammates but also have the luxury of immediate feedback from their peers. 
Feyera Beyessa

\section{Social- Emotional Benefits}

In 1991, the US Department of Labor conducted a nationwide survey to investigate what skills employers most seek in their new employees. The purpose of this survey was to get the business world's "take" on what schools could do to better prepare American worker for highly skilled, highly profitable jobs. While technical skills and general intelligence proved important, the skills most often cited were "communication skills, interpersonal skills and initiative" (Dowd and Liedtka, 1994). In the document from the US state department entitled "What Work Requires of Schools," among the top attributes US employers most desired were: sociability, selfmanagement ability to participate as member of a teamcontributes to group effort, ability to exercises leadership and ability to work with diversity.

\section{Johnson, Johnson and Smith's five Pillars / Elements of $\mathrm{CL}$}

Johnson, Johnson, and Smith (1991) define cooperative learning as "the instructional use of small groups so that students work together to maximize their own and each other's learning." Based on their research, they have proposed five essential elements that are necessary to make students to be cooperative learner in constructing their effective cooperative learning experiences which are presented in the following pages one after the other.

Positive Interdependence: Positive Interdependence is the belief that the individual is dependent on the contributions, inclusion, and success of the others in the group in order to be successful. Those with a strong sense of positive interdependence believe that there is value in learning from the ideas and contributions of others and that "group members sink or swim together" (Johnson, Johnson and Smith, 1991). As they describe, "if there is no positive interdependence, there is no cooperation." these specific types of interdependence as product goal interdependence, resource interdependence and role interdependence.

Promotive Face- to- Face Interaction: Promotive faceto-face interaction is a foundational component to cooperative learning. The result of promotive face-to-face interaction occurs when students are given time in class to discuss, ask questions and support each other in the completion of their task. Students must understand that it is not only the final product that matters in cooperative learning but also the ongoing dialogue process that is a critical part of their success. There are two aspects to this. The first is the physical proximity needed for effective communication, or 'eye-to-eye and knee-to-knee'. The second is that it supports thinking skills by more active involvement with the task and greater discussion. Oral summarizing, giving and receiving explanations, and elaborating (relating what is being learned to previous learning) are important types of verbal interchanges (Johnson, Johnson and Smith, 1991).

Individual Accountability: As a result, students who are understandably concerned about grades must feel that they are individually accountable for their performance in groups in order for cooperative learning to be successful. An obvious issue of concern for students in cooperative learning setting is 'social loafing' whereby one student does all of the work while the rest of the group gets a free ride. As a pillar for cooperative learning, individual accountability ensures that "students learn together, but
Sci. Technol. Arts Res. J., July-Sep 2015, 4(3): 279-284

perform alone" (Johnson, Johnson and Smith, 1991). CL groups are not successful until every member has learned the material or has helped with, and understood, the assignment.

Social Skills: Much to the dismay of educators, placing students in close proximity to each other with a task to accomplish does not ensure cooperative learning will take place (Johnson and Johnson, 1994). Often it is not a matter lack of interest or defiance, but rather students (even at the college level) do not have the social skills necessary to work effectively with others. Just as teachers build academic skills to ensure cognitive gain, for cooperative learning to be successful, teachers need to use the same dynamic and intentional teaching of social skills (Optiz, 2008), and students need to collaborate effectively with others, so teachers need to teach the appropriate communication, leadership, trust-building, decision-making and conflict-management skills to students and provide the motivation to use these skills in order for groups to function effectively.

Group Processing: Cooperative Learning theorists Johnson, Johnson and Smith (1991) more specifically stated that reflection is central to all cooperative learning. Cooperative learning is a very well-researched yet underutilized pedagogical strategy in the college classroom (Weimer, 2008). Regardless of subject matter, the age of the students or academic ability, if utilized correctly under Johnson, Johnson and Smith's (1991) five pillars, cooperative learning will only enhance student performance and success. Processing means giving pupils time and procedures to analyze how well their groups are functioning and using the necessary skills. This reflection identifies group strengths and goals. It helps all group members achieve while maintaining effective working relationships among members. Feedback from the teacher and/or student observers on how well they observed the groups working may help processing effectiveness.

In this connection, cooperative classroom pattern, commonly called one- in- five learning has been generally accepted and implemented in the college since 2010/2011 G.C. so as to produce students of problem solving capacity for the country with sitting arrangement of heterogeneous group of students of the same class are sitting around one table. In cooperative learning classroom, which is a stagnant approach having heterogeneous groups of students throughout the year, and female students within their cooperative groups are expected to attempt a problem solving strategy, stressing recent successes among members of the group and competent learners.

Even though $C L$ requires pupils to work together in small groups to support each other to improve their own learning and those of others, Paulsen and Faust (2008) note that there is still a resistance and hesitation in higher education to transform traditional college classes into CL environments. Despite the pedagogical interest, under the false notions that $\mathrm{CL}$ is an alternative to, rather than an enhancement of professorial lectures, many avoid integrating $\mathrm{CL}$ into their classes (Pausen and Faust, 2008). In fact, according to Weimer (2008) when asked about the teaching methods they most commonly employ, $76 \%$ of college professors reported that lecture was their "primary approach" to teaching, and CL it is not common practice (Fink, 2004). Due to the expert nature of higher 
Feyera Beyessa

education, much evidence suggests that many college professors still cling to the notion of expounding knowledge to their students rather than engaging them in discovering such knowledge through active learning (Ediger, 2001).

Similarly, there is also a general confusion as to what the term 'cooperative learning' means. Very often, this phrase is a blanket term, applied to any sort of group work or interaction between classmates that results in a product. Educators often operate under the false assumption that putting adults in groups automatically assumes that they are being 'cooperative' and that they are 'learning' and neither of these assertions is necessarily true (Johnson and Johnson, 1994). As Johnson and Johnson argued and as a researcher also supports, by only forming groups we cannot be so sure of students learning. To give evidence of this, for example in our college where cooperative learning is largely being practiced, a great number of female students are under warning and most of them are also dismissed from third year batch alone. Five male and 48 female students of Natural Science and Mathematics Departments of Mettu College of Teacher Education, out of total number of 202 male students and 297 female students of third year teacher educators were under warning and totally dismissed in 2014 respectively. This shows that, number of dismissal and warning of female students were by far (9.6 times) greater than male students.

Another reason for a lack of either interest or success with cooperative learning is that it can be problematic and teachers have worried over the ability to effectively assess pupils as individuals when they work in their CL (Jolliffe, 2007). There are also some misconceptions that groups of students sitting together at one table and talking about their assignments and class works were considers as CL, but not. These gaps were inspired the researcher to assess female students' perceptions, practices and challenges in $\mathrm{CL}$ at Mettu College of Teacher Education.

\section{MATERIALS AND METHODS}

A descriptive case study is one that is focused and detailed, in which propositions and questions about a phenomenon are carefully scrutinized and articulated at the outset (Gerring, 2007). To this end, the method used is the descriptive case study research method to assess the in depth perception, practice and challenges female students in their $\mathrm{CL}$.

\section{Source of Data}

Primary data sources include students, science and mathematics teachers, gender coordinator, and vice Dean College. The secondary data sources were student records and other documents with respect to activities in the college.

\section{Samples and Sampling Techniques}

Mettu College of teacher education was selected using purposive sampling technique for the researcher has been teaching in it. Out of 273 third year female students, first stratified sampling was used to divide $72(26.4 \%)$ them in to three groups (low, medium and high achievers) and then followed by simple random sampling (lottery method) to select them with equal proportion for they are in the same grade level and stayed in the college for three years. Availability sampling was used to select 6 science and mathematics teachers the direct implementers of the
Sci. Technol. Arts Res. J., July-Sep 2015, 4(3): 279-284

curriculum, 1 vice dean and 1 gender coordinator for they are the front concerned bodies of gender issues. Thus, the subjects of the study were 80 . It is important to note that female students were categorized according to their grade point average. That is high achievers are who scored $\geq 3.0,3.0<$ medium achievers $>2.0$, and1.75 $\leq$ low achievers $\leq 2.0$.

\section{Data Gathering Instruments}

The questionnaires of open-ended ( 5 items) and closeended (40 items) having 5 degree of agreement of the questionnaire were based on the Likert-type opinion of five scales. In addition, 6, 5 and 9 set of interviews were used for college vice dean, gender coordinator, subject teachers and respectively. Moreover, 12 focused group discussion for female students were used. Finally, document analysis was carried out on students mark list, teachers attendance and activities done relative to CL.

\section{Procedure and Data Analysis Strategy}

After developing the data collecting instruments, the researcher has given to two science and mathematics teachers so as to improve the validity of the questionnaire and then a pilot test of instruments was made in both 16 students respondents to make the instruments dependable and to be finally used in the actual study with the overall Cronbach's alpha 0.93 . This shows that the instruments were highly reliable to collect relevant information. Data gathered through the closed questionnaire were analyzed using both descriptive (Mean) and inferential statistics (One way ANOVA) so as to see the statistical significance among low, medium and high achievers of female students in their perceptions and practices of $\mathrm{CL}$ at 0.05 confidence levels. Finally, data gathered were analyzed qualitatively.

\section{RESULTS AND DISCUSSION}

Table 1 indicates the one way ANOVA analysis of high, medium and low achievers of female students' perception of cooperative learning in mathematics and science education. The result of female students perception $(F \geq 0.06, \mathrm{df}=2, p>0.05)$ revealed that there were statistically no significant difference among high, medium and low achievers of female students of perceptions of cooperative learning. Except few $(\mathrm{M}=0.7)$ female students, majority $(M=4.3)$ of female students have strongly believe the academic and social emotional benefits of cooperative learning in their teaching process so as to enhance their cognitive learning, self - evaluation and self-assessment, ability to participates as member of a team, sociability, concepts of learning and the like. On top of this, the data from focus group discussion made on 17January 2014 also reveals that majority of female students have positive perception toward CL. For instance:

Through focus group discussion, majority of female students stressed that, we believed CL helps us to understand, respect, and support one another so as to improve our self-esteem, establish positive interpersonal relationships, and foster positive interdependence. It assists us in developing higher level academic skills in different academic disciplines particularly in mathematics and science education to acquire skills for effective communication by creating learning environments similar to real life situations. CL encourages students to interact, ask and answer questions, solve problems, and make decisions in improving our teaching learning. 
Table 1: One way ANOVA of Female Students' Perceptions toward CL

\begin{tabular}{|c|c|c|c|c|c|}
\hline Items & $\begin{array}{l}\text { Source of } \\
\text { variation }\end{array}$ & $\begin{array}{l}\text { Sum of } \\
\text { Squares }\end{array}$ & $\begin{array}{l}\text { Mean } \\
\text { Square }\end{array}$ & $\mathbf{F}$ & $p$-Value \\
\hline Maximize your own learning & $\begin{array}{l}\text { Between Groups } \\
\text { Within Groups }\end{array}$ & $\begin{array}{c}1.7 \\
34.2\end{array}$ & $\begin{array}{l}0.85 \\
0.49\end{array}$ & $1.72^{*}$ & 0.18 \\
\hline Increase cognitive learning & $\begin{array}{l}\text { Between Groups } \\
\text { Within Groups }\end{array}$ & $\begin{array}{c}1.7 \\
51.7\end{array}$ & $\begin{array}{l}0.86 \\
0.75\end{array}$ & $1.15^{*}$ & 0.32 \\
\hline Helps to understand concepts of learning & $\begin{array}{l}\text { Between Groups } \\
\text { Within Groups }\end{array}$ & $\begin{array}{c}1.1 \\
114.4 \\
\end{array}$ & $\begin{array}{c}0.57 \\
1.6\end{array}$ & $0.349^{*}$ & 0.70 \\
\hline $\begin{array}{l}\text { Helps for on time academic accomplishments of your } \\
\text { classmates }\end{array}$ & $\begin{array}{l}\text { Between Groups } \\
\text { Within Groups }\end{array}$ & $\begin{array}{c}1.2 \\
39.5 \\
\end{array}$ & $\begin{array}{l}0.64 \\
0.57\end{array}$ & $1.12^{*}$ & 0.33 \\
\hline Give opportunity to develop friend and sociability & $\begin{array}{l}\text { Between Groups } \\
\text { Within Groups }\end{array}$ & $\begin{array}{c}1.8 \\
65.2 \\
\end{array}$ & $\begin{array}{c}0.921 \\
0.94\end{array}$ & $0.97^{*}$ & 0.38 \\
\hline Helps to develop self - evaluation and self-assessment & $\begin{array}{l}\text { Between Groups } \\
\text { Within Groups }\end{array}$ & $\begin{array}{c}3.5 \\
44.4\end{array}$ & $\begin{array}{c}1.7 \\
0.64\end{array}$ & $2.7^{*}$ & 0.06 \\
\hline $\begin{array}{l}\text { Help to expand ability to participates as member of a } \\
\text { team }\end{array}$ & $\begin{array}{l}\text { Between Groups } \\
\text { Within Groups }\end{array}$ & $\begin{array}{l}0.12 \\
47.8\end{array}$ & $\begin{array}{l}0.06 \\
0.69\end{array}$ & $0.08^{*}$ & 0.91 \\
\hline $\begin{array}{l}\text { Increase to exercises leadership and team } \\
\text { management }\end{array}$ & $\begin{array}{l}\text { Between Groups } \\
\text { Within Groups }\end{array}$ & $\begin{array}{l}0.27 \\
65.3\end{array}$ & $\begin{array}{l}0.13 \\
0.94\end{array}$ & $0.14^{*}$ & 0.86 \\
\hline $\begin{array}{l}\text { Develops ability to work with diversity- works well with } \\
\text { men and women }\end{array}$ & $\begin{array}{l}\text { Between Groups } \\
\text { Within Groups }\end{array}$ & $\begin{array}{l}0.14 \\
73.8\end{array}$ & $\begin{array}{l}0.07 \\
1.07\end{array}$ & $0.06^{*}$ & 0.93 \\
\hline
\end{tabular}

${ }^{*}=\mathrm{P}>0.05$, between the groups $\mathrm{df}=2$ and Overall mean score, $\mathrm{M}=4.3$

Table 2 indicates the one way ANOVA analysis of high, medium and low achievers of female students' practices in their cooperative learning $\mathrm{g}$ in mathematics and science education. The result of female students perception $(F \geq 3.38, \mathrm{df}=2, p<0.05)$ revealed that there were statistically significant difference among high, medium and low achievers of female students in practicing the five pillars of cooperative learning. This statistical difference of female students directly implies that there were great gaps among high, medium, and low achievers of female students to be involved in effective practice of $\mathrm{CL}$ as clearly shown in the Figure1.

Table 2: One way ANOVA of female students' practices in cooperative learning

\begin{tabular}{|c|c|c|c|c|c|}
\hline $\begin{array}{l}\text { Elements of Cooperative } \\
\text { Learning }\end{array}$ & $\begin{array}{l}\text { Source of } \\
\text { Variation }\end{array}$ & $\begin{array}{l}\text { Sum of } \\
\text { Squares }\end{array}$ & $\begin{array}{l}\text { Mean Square } \\
\text { Variance }\end{array}$ & $\mathbf{F}$ & $p$-value \\
\hline Positive Interdependence & $\begin{array}{l}\text { Between Groups } \\
\text { Within Groups }\end{array}$ & $\begin{array}{l}14.7 \\
55.2\end{array}$ & $\begin{array}{l}7.36 \\
0.80\end{array}$ & $9.19^{* *}$ & 0.000 \\
\hline $\begin{array}{l}\text { Promotive Face to Face } \\
\text { Interaction }\end{array}$ & $\begin{array}{c}\text { Between Groups } \\
\text { Within Groups }\end{array}$ & $\begin{array}{c}8.2 \\
55.0 \\
\end{array}$ & $\begin{array}{l}4.12 \\
0.79 \\
\end{array}$ & $5.17^{\star *}$ & 0.008 \\
\hline Individual Accountability. & $\begin{array}{c}\text { Between Groups } \\
\text { Within Groups }\end{array}$ & $\begin{array}{c}3.9 \\
40.6 \\
\end{array}$ & $\begin{array}{l}1.99 \\
0.58\end{array}$ & $3.38^{* *}$ & 0.040 \\
\hline Social Skills & $\begin{array}{l}\text { Between Groups } \\
\text { Within Groups }\end{array}$ & $\begin{array}{c}5.1 \\
24.7\end{array}$ & $\begin{array}{l}2.57 \\
0.35\end{array}$ & $7.16^{\star \star}$ & 0.001 \\
\hline Group Processing & $\begin{array}{c}\text { Between Groups } \\
\text { Within Groups }\end{array}$ & $\begin{array}{l}30.7 \\
75.2\end{array}$ & $\begin{array}{c}15.38 \\
1.09 \\
\end{array}$ & $14.10^{* *}$ & 0.000 \\
\hline
\end{tabular}

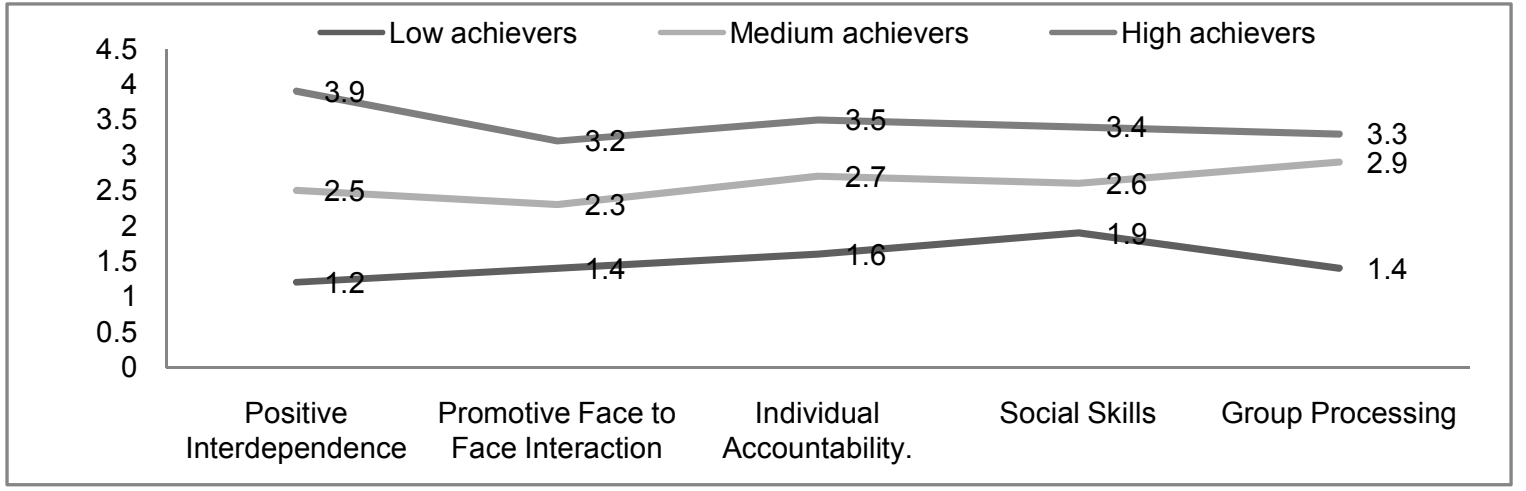

Figure 1: Level of high, medium and low achievers of female students' practices in CL

Regardless of subject matter, the age of the students or academic ability, if utilized correctly under Johnson, Johnson and Smith's (1991) five pillars, cooperative learning will only enhance students' performance and success by swimming together equally. Contrary to this, as can be seen from chart1, only the mean score of high achievers of female students have been relatively greatest to be involved in practicing the elements of $C L$ with overall mean score $(M=3.46)$.

However, the practices of medium, and low achievers in $C L$ were respectively, $M=2.6$ and $M=1.5$ mean scores. Which are very near to the ground practices so as to accomplish all activities equally with the group members, 
Feyera Beyessa

share ideas to give general points and conclusions, developing sense equal personal responsibility and accountability to learn and to help the rest members, show conflict management skills through resection, and get the opportunity to reflect their constrictive skills.

Majority of low and medium learners of female students replied that, we were grouped in one in five heterogynous groups having different ability and sex in sitting around a table to implement $\mathrm{CL}$ as a part of a group of teachinglearning techniques where students interact with each other to acquire and practice the contents of a subject matter and to meet common learning goals. Yet, while doing so, fast learners showed a sense of silence, ignoring female students' idea /contribution and not to make the slow learners the same understanding with other group members. They also said that a group of students working on a group assignment where one student takes the lead and completes the work, and all the other students put their names on the assignment, project works and other activities (focus group discussion made on 17 Jan, 2014).

From this finding the researcher can conclude that groups of students sitting together at one table and talking about their assignment as they individually work on their assignment and project works is not CL. Hence, from the analysis one can realize that the five pillars of cooperative learning were only practiced by few active female students, who were competent among the heterogeneous group members. Whereas, all of low achievers and majority of medium achievers of female students were practicing below the normal practice to accomplish a common goal and they were dominated by active students of the group members to obtain greatest performance.

\section{Challenges of female students in $C L$}

Challenges Related to Female Students (themselves): The primary role of the learner is to contribute to the completion of the group tasks while collaboratively working with the members of the group. Because they are taught how to organize their study to keep their group working and to monitor and assess their learning process, they become the directors of their own learning (Johnson, Johnson and Smith, 1991). However, since they are offcampus college-students, they identified the following challenges (focus group discussion made on 17 Jan 2014)

Giving low status for themselves in $\mathrm{CL}$, and spending their time on other /extra activities (eg. searching extra business by washing clothes for some, fetching water, doing other household activities to survive for the fact that they are off- campus learners, showing a sense poor self- confidence and self- initiative in doing all activities in front of active learners, taking no responsibility and accountability in CL, feeling a sense of fed up due to fixed/ permanent group members and joking, simply sitting and listening/accepting the high achievers reflection, giving the opportunity for fast learners to accomplish all activities (assignment, group work, project work and others) of CL and having lack the skills to work in group. They exercised to put their names on the assignment, group activities, project works without any effort/accountability .

Challenges Related to Male Students Group Members: According to Johnson, Johnson and Smith (1991), when cooperative learning is used for students to learn, understand, respect, interact, ask and answer questions, solve problems, and make decisions establish
Sci. Technol. Arts Res. J., July-Sep 2015, 4(3): 279-284

positive interpersonal relationships, foster positive interdependence and support one another. Yet the following challenges were identified through focused group discussion made on 17 January, 2014:

Superiority of male students over female students in $\mathrm{CL}$, some male students show sense of inequality, less interest to work together or with the group members, and male students domination and rejecting female students idea on critical reflection/ feedback on the lesson, non participation of all members of the group, unwillingness of active male students to react on the science and mathematics of the subject matters, for they were selfish to get excellent grade for themselves for the fact that the grade system of the college is not fixed. While practicing $\mathrm{CL}$, male students need various benefits from female student.

Challenges Related to Subject Teachers: In preparing the students of today to become successful individuals of tomorrow, science and mathematics teachers need to ensure that their teaching is effective. Teachers should have the knowledge of how students learn science and mathematics through $\mathrm{CL}$ and how best to teach. Female students have been pointed out following challenges, which are related to teachers (focus group discussion on18 January, 2014):

i. Some teachers give group work, assignment, projects and other common activities nevertheless, assessing and evaluating individual student learning and help students process how well their groups functioned were not checked;

ii. Some teachers show less activity to encourage in their $\mathrm{CL}$, even while learning the lesson, instead of saying for female students please respond to the question, they used the word/statements: try, would you try?, can you try? And the like, which may demoralize their interest to react on the lesson critically;

iii. Some teachers have limited knowledge on how to practice the essential elements of CL;

iv. Some teachers are failing to use effective and various strategies of CL such as jigsaw, think-pair share, three step interview, inside-outside circle, student achievement division, and so on.

Challenges Related to Institution: From the focused group discussion of female students and interview made with gender coordinator and vice dean of the college and document analysis, the researcher has identified the following major challenges related to the college. These challenges are luck/ absence of:

a) Written policy regarding the pedagogical and scientific implementation of $\mathrm{CL}$;

b) Produce guidelines/ rules and regulations for $\mathrm{CL}$ environment of heterogeneous group;

c) Common understanding among female students and all staff members;

d) Monitoring and evaluating the effectiveness of CL;

e) No special meeting on the issue of female students' $\mathrm{CL}$ practices and challenges with the overall staff members;

f) Clear vision and strategic plan which incorporates all staff members of $\mathrm{CL}$ implementers and

g) Giving tangible pre- instructional discussions/ trainings on the issue of $\mathrm{CL}$ for teachers and female students. 


\section{CONCLUSIONS}

It has been found that even though majority female students have strongly perceived $C L$ positively $(M=4.3)$, some female students showed negative perceptions $(M=0.7)$ to $C L$ in their teaching learning. Therefore, to realize effective teaching learning process, the college should give trainings on the current issues, values and objectives, and principles of $\mathrm{CL}$ for students in general and for female students in particular so that they can believe and internalize it further significantly. The research result depicted that with statistically difference among the groups of all low achievers and majority of medium achievers of female students were practicing below the ordinary practice to accomplish a common goal and they were highly dominated by fast learners of the group members. Thus, the college, gender coordinator, and the subject teachers have to give guidance for low and medium achievers of female students on how to practice the five pillars of the CL. They also have to give guidance for the fast learners/heterogeneous groups to work equally with the slow and medium female learners to achieve the common goal of CL.

The findings of the study revealed that majority of female students have been taking very less responsibility and accountability in their CL practices and they spend their time on extra fund raising house hold activities. Thus, the gender office coordinator has to give individual advice, financial, psychological and material support for female students so that they can give priority $\mathrm{CL}$. The outcome of the study showed that unwillingness of active male students to react on the science and mathematics of the subject matters so as to use their golden study time and some male students show sense of superiority, inequality, less interest to work slow learners of female students in $\mathrm{CL}$. Thus, the college and gender coordinator office have to give pre- instructional training on the issue of equity, humanity, fairness, basic elements of cooperative learning, and the like so as to achieve mutual goals

From the results of investigation, some subject teachers showed less effort to give special attention and equal treatment of group members with effective strategies of CL. Some teachers also make obviously fewer activities in assessing and evaluating individual student learning and help students process how well their groups functioned.Thus, as first line implementers of the curriculum, the subject matter teachers have to play a great role to make a number of pre instructional decisions, explain the task to female student and the concept of positive interdependence, monitor individual students' learning and intervene to assist students with interpersonal and group skills, and assess and evaluate students' learning with equivalent treatment and professional support in completing the task accurately. The results of the study also indicates that the college is at poor performance in arranging and organizing facilities, monitoring and evaluating class room patterns and the implementation of $\mathrm{CL}$, organizing regular female students, making pre-instructional discussions with staff members to solve female students challenges in their $\mathrm{CL}$. Particularly in teacher education classes, where groups of students sitting together at one table and talking about their assignment as they individually work on their assignments and where one student takes the lead, completes the work, and all the other female students put their names on the assignment.
There should be a clear policy that clearly show the pedagogical and scientific approaches of CL implementation in the collage so that some collage stakeholders (female students, subject teachers and the college dean and gender office coordinators) have to be comfortable, develop understandings and put emphasis for the implementation of CL in mathematics and science education. Since this research is new in our educational context, there should be further research to be investigated on the implementation, effectiveness, strategies of $C L$ and the like.

\section{Conflict of Interest}

Conflict of interest none declared.

\section{REFERENCES}

Barkley, E., Cross, K. and Major, C. (2005). Collaborative Learning Techniques - A Handbook for College Faculty. San Francisco: Jossey-Bass.

Dowd, K.O., and Liedtka, J. (1994). What corporations seekin MBA hires: A survey. The Magazine of the Graduation management Admission Council 2.

Ediger, M. (2001). Learning opportunities in the higher education curriculum. College Student Journal 35(3): 410.

Fink, L.D. (2004). Beyond small groups: Harnessing the extraordinary power of learning. In Michaelsen L., Knight, A. and Fink L.D. Team-Based Learning: A transformative use of small groups. Sterling, VA: Stylus Publishing.

Gerring, J.(2007). Case Study Research. Principles and Practices. Newyork: Cambridge University Press.

Johnson, D.W., Johnson, R.T. (1994). An overview of cooperative learning. In: Thousand, J., Villa A. and Nevin A. (Eds). Creativity and Collaborative Learning. Baltimore, MD: Brookes Press.

Johnson, D.W., Johnson, R.T., and Smith, K.A. (1991). Active learning: Cooperation in the college classroom. Edina, $\mathrm{MN}$ : Interaction.

Jolliffe, W. (2007). Cooperative Learning in the Class room. Putting in to practice. New Delhi, SAGE Publications India Pvt Ltd.

Opitz, C. (2008). SEL Overall Plan. Retrieved in July 14 , 2013 from http://www.edutopia.org/pdfs/coopmathbowma /bowmanseloverallplan.pdf.

Paulson, D.R., and Faust, J.L. (2008). Active Learning for the College Classroom. Retrieved July 15, 2008 from http://www.calstatela.edu/dept/chem/che/Active/main.htm.

Slavin R. (1996). Research on Cooperative Learning and Achievement: What We Know, What We Need to Know. Contemporary Educational Psychology 21(1): 43-69.

Terenzini, P.T., Cabrera, A.F., Colbeck, C.L., Bjoklund, S.A. (2001) Collaborative learning vs. Lecture/discussion: Students' reported learning gains. Journal of Engineering Education 90(1):123-130.

Weimer, M. (2008). Active Learning Advocates and Lectures. Retrieved July 18, 2008 from http://teachingprofessor. blogspot.com/2008/06/active-learning-advocates-andlect ures.html

Williams, R.B. (2007). Cooperative Learning: A Standard for High Achievement. Thousand Oaks, CA: Corwin Press. 